\title{
Tropical and Subtropical Fruit Crops for the Home Landscape: Alternatives to Citrus ${ }^{1}$
}

\author{
Jonathan H. Crane, Carlos F. Balerdi and Michael S. Orfanedes ${ }^{2}$
}

\section{Introduction}

Bacterial citrus canker and now citrus greening have ravaged citrus plantings throughout Miami-Dade and Broward Counties and much of south Florida. Infected trees may severely defoliate and management options are very limited; sanitation procedures and following quarantine regulations are very important. Because of the highly infectious nature of these citrus diseases fruit crops other than citrus should be considered for planting in the home landscape. For some residents, that could mean the opportunity to grow some exciting tropical and subtropical fruit crop alternatives.

The south Florida climate offers the opportunity to successfully produce a surprising variety of tropical and subtropical backyard fruits. Many of them have strange names, odd shapes and exotic flavors, particularly for those of us who have come from up north. Yet many of these fruits are tempting, nutritious, and luscious old favorites enjoyed by the peoples of the tropics around the globe. Examples include, avocado, mango, guava, and papaya or perhaps the even more exotic carambola, jakfruit and jaboticaba. Although many of these species can attain the size of large trees, routine pruning can keep them to a manageable size for most backyard situations.

The University of Florida, Institute of Food and Agricultural Sciences has a wealth of information on how to grow and enjoy these and many other tropical and subtropical fruits right here in south Florida. Learn which varieties are adapted to our area, recommended cultural practices, pitfalls, and preparation techniques. Free publications on tropical fruit crops and nursery location information is available from the Miami-Dade County (tel: 305-248-3311), Broward County (tel: 954-370-3725), and Palm Beach County (tel: 561-233-1712) Cooperative Extension Service. Free publications may also be viewed and downloaded for printing at the University of Florida (UF), Institute of Food and Agricultural Service, Electronic Digital Information System (edis) World Wide Web site at http://edis.ifas.ufl.edu (hint: search the edis site by key words, for example, mango). For sale UF

1. This document is HS812, one of a series of the Horticultural Sciences Department, Florida Cooperative Extension Service, Institute of Food and Agricultural Sciences, University of Florida. Original publication date July 2001. Revised October 2005. Visit the EDIS Web Site at http://edis.ifas.ufl.edu. 2. Jonathan H. Crane, Tropical Fruit Crop Specialist, University of Florida, Tropical REC, Homestead, Carlos F. Balerdi, Multi-County Tropical Fruit Crops Extension Agent, Miami-Dade County Cooperative Extension Service, Homestead, and Michael S. Orfanedes, Commercial Horticulture Extension Agent, Broward County Division of Agriculture and Extension Education, Davie; Acknowledgement: Contributions from William Hopkins Jr., Hopkins Rare Fruit Nursery, Ft. Lauderdale.

The Institute of Food and Agricultural Sciences (IFAS) is an Equal Opportunity Institution authorized to provide research, educational information and other services only to individuals and institutions that function with non-discrimination with respect to race, creed, color, religion, age, disability, sex, sexual orientation, marital status, national origin, political opinions or affiliations. U.S. Department of Agriculture, Cooperative Extension Service, University of Florida, IFAS, Florida A. \& M. University Cooperative Extension Program, and Boards of County Commissioners Cooperating. Larry Arrington, Dean 


\section{publications may be found on the World Wide Web at http://ifasbooks.ufl.edu/.}

Below is an overview of some of the fruits we think local residents might want to grow and several (guava and sapodilla) that the University of Florida, IFAS does not recommend because of their invasive status. For more information on the invasive status of various plant species please see: Fox, A.M., D.R. Gordon, J.A. Dusky, L. Tyson, and R.K. Stocker (2005) IFAS Assessment of the Status of Non-Native Plants in Florida Natural Areas [Cited from the Internet (6 Jan., 2006) from http://plants.ifas.ufl.edu/assessment.html].

\section{Atemoya (custard apple)}

The atemoya is a hybrid between the sugar apple and cherimoya. It produces a fruit very similar to the sugar apple, also called sweetsop or anon. It is a small to medium sized, open, deciduous tree with a rounded canopy rarely exceeding 20 feet in height and width. Because of their relatively small stature, atemoya trees are suited to small yards. A relative of the atemoya, sugar apple has similar characteristics. The fruit is heart-shaped, round, ovate or conical, from 2 to 4 inches in diameter. The pulp is white or creamy white, with a custard-like consistency and a sweet, pleasant flavor. When ripe, atemoyas become light green or yellow-green in color. The pulp of atemoya is consumed principally as a dessert fruit and has an excellent flavor. It may be eaten fresh but it may also be used to make a tasty ice cream or milkshake. Season: late Aug.-Oct., sometimes Dec. -Jan.

\section{Avocado}

Perhaps one of the best known subtropical fruits, avocado trees are typically medium to large in size (40-60 feet), easy to grow and can produce large quantities of fruit. Limbs are vulnerable to wind damage and can even break under the weight of a heavy fruit load. The fruit is a very large berry consisting of a single large seed surrounded by a buttery pulp. Mature fruit are generally green, although some cultivars may be black, red or purple when soft (ripe). Avocados do not ripen until they are picked or fall to the ground. Mature fruit size varies considerably depending upon cultivar and growing conditions. Avocados are highly nutritious. Fruit are popular eaten fresh, in salads or used to make guacamole and other dishes. Planting in a well-drained site is a must, as avocados do not tolerate flooding. Productivity, season of maturity, cold tolerance, and disease tolerance vary greatly depending upon the variety under consideration. Season: late May to March.

\section{Banana}

A true tropical favorite, bananas are perhaps the best known of the tropical fruits. There are many different cultivars available with a wide variation in fruit type and quality. Bananas are not cold tolerant and some varieties are better adapted to south Florida than others. Growth is extremely rapid during the very warm, wet summer months. Because they reproduce from underground rhizomes and not seed, a single plant can quickly spread out producing multiple trunks in a matter of a few months. Fruits develop in clusters on the end of flower stalks usually within 1-2 years. Shortly after bearing, the stem dies. Bananas like full sun and moist but well drained soil. They will tolerate partial shade, but best growth and fruit production is in full sun. Bananas may be eatten fresh, fried, baked, and added as a component to deserts and drinks. Season: year round.

\section{Caimito (star apple)}

Native to Central America and the West Indies, this evergreen tree is highly ornamental and produces a sweet purple or green fruit. Trees may reach 25 to $100 \mathrm{ft}$ in height and have a dense, broad crown. The attractive leaves are glossy and green on the upper surface and golden brown on the under surface. Trees produce either light green or purplish colored fruit. The fruit is round, 2-4 inches in diameter, and may have a dark-purple or white flesh. The flesh is milky, sweet, and gelatinous and surrounds up to 10 seeds. Plant trees in a well-drained soil and sunny location. Season: Jan.-June.

\section{Carambola (star fruit)}

Originally from southeast Asia, star fruit is becoming increasingly popular and available in the 
U.S. Locally, commercial production occurs in the southern half of south Florida. Trees are generally small to medium in height ( 35 feet max.) and spreading with the majority of fruit borne on branches in the mid-canopy region. The fruit is a large fleshy berry, 2-6 inches in length, yellow skinned with a waxy surface and star-shaped cross section. Flesh is light to dark yellow, translucent, crisp and very juicy. Better cultivars have a nice, slightly sweet to subacid flavor. Eat fresh, cut up in fruit salads, or as an iced juice drink. The fruit may also be canned, preserved, and dried.

Carambola trees also have ornamental value with their dark green foliage and attractive flowers and fruit. Plant in a well-drained soil and sunny location, which has protection from wind. On alkaline soils (those with high $\mathrm{pH}$ ) watch for signs of minor element deficiencies, particularly zinc, iron, and manganese and treat accordingly. Season:

July-September, Nov.-Feb.

\section{Canistel (egg fruit)}

Native to southern Mexico, Belize, Guatemala, and El Salvador, this evergreen tree is ornamental and produces a sweet yellowish-orange top-shaped fruit. Trees may reach $25 \mathrm{ft}$ or so in height with leaves mostly grouped at the ends of branches. The attractive lanceolate-shaped leaves are glossy and green. Trees produce 3-5 inch long by 2-3 inch diameter, conical-shaped fruit. The maturing fruit changes from green to light green to golden-yellow or pale orange-yellow at maturity. After picking allow fruit to become soft before eating. Soft fruit will have a yellow-orange flesh, which is smooth with a sweet to musky flavor. Eggfruit is eaten fresh and used in making milk shakes. Plant trees in a well-drained soil and sunny location. Season: Dec.-May.

\section{Jaboticaba}

Native to Brazil, jaboticaba is an unusual tree that produces a purple, grape-like berry directly upon the trunk and larger branches either singly or in clusters. Under the skin is a whitish pulp with 1 to 4 seeds. The fruit has a pleasant flavor and taste a bit like grape. They can be eaten fresh or made into jam, jellies or wine. Flowering and fruiting occur periodically throughout the year so multiple crops are produced. Other than its fruit, jaboticaba is known for its beautiful multicolored bark, which gives it value in the landscape. The tree is small, slow growing, and bushy, and seldom exceeds 20 feet in Florida. Flowers are small and white, interesting but rather inconspicuous and borne right on the trunk and larger branches. Jaboticaba is relatively hardy but will not tolerate drought. Plant in full sun in a moist but fairly well drained soil. The tree prefers a slightly acid soil, so some special attention will be required to provide the proper nutrition on our alkaline soils. If provided with an ideal growing environment, jaboticaba can be a relatively low maintenance tree requiring little pruning or spraying for pests. Season: variable.

\section{Jackfruit (jakfruit)}

Native to India and Malaysia, this attractive large tree has glossy, dark green leaves and produces a very large, oval shaped, rather unusual looking segmented (spiked) fruit. Typically, fruit are produced in clusters of 2 or more at various height intervals along the trunk. The skin of the fruit must be peeled to reveal the succulent, yellow to orange colored pulp. Because of sticky latex in the peel, coat your hands with vegetable oil prior to peeling a jackfruit. This will make clean up a lot easier. The flavor is sweet, not unlike that of banana or pineapple, but with a strong, fruity aroma and taste. Fruit may be used fresh, fried green, pickled or roasted (seeds). Jackfruit must be planted in flood free, well-drained soils. In south Florida, jakfruit trees have few serious pest or disease problems. Season: spring-fall (some all year round).

\section{Longan}

Indigenous to Mayanmar (Burma), southern China, southwest India, Sri Lanka, and the Indochinese peninsula, longan is large tree (30-40 ft). Longan is an excellent fresh fruit with a pleasant, unique, sweet flavor. Fruit are relative small (about the size of a typical strawberry), round to oval, and borne in loose clusters. When fruit are ripe, the leathery skin develops an attractive golden brown color. Longan trees are attractive having a dense, round to upright, symmetrical canopy of dark green foliage. They may grow as high as 40 feet. Plant in 
sunny, well-drained sites. Trees may begin to bear within 3-5 years of transplanting. However, unreliable bearing is a major constraint. Season: July-Aug.

\section{Lychee (litchi)}

Lychee trees are native to southern China and southeast Asia and may grow to 40 or more feet in height. Lychee is an excellent fresh fruit with a pleasant, sweet flavor. Fruit are a relatively small (about the size of a typical strawberry), round to oval, and borne in loose clusters. When fruit are ripe, the leathery skin develops an attractive pinkish red color. Lychee trees are attractive having a dense, rounded, symmetrical canopy of dark green foliage. They may grow as high as 40 feet. Plant in sunny, well drained sites, preferably where there is some protection from wind. Trees may begin to bear within 3-5 years of transplanting. However, unreliable bearing is a major constraint. Season: June, early July.

\section{Mamey sapote}

Native to Mexico and the Central American lowlands, mamey sapote trees are large and erect reaching a height of about 40 feet in Florida. Mamey sapote makes an excellent specimen tree in the home landscape with handsome glossy foliage. The fruit has a brown, scurfy peel and the flesh of mature fruit is salmon pink to reddish brown in color and has a unique, sweet flavor. The tree grows well in a variety of soils, but requires good drainage. Mamey sapote can be eaten fresh, and is also excellent for use in ice cream, sherbets, jellies, and preserves. Milkshakes may also be prepared from the flesh. It requires little care and yields a useful, good tasting fruit. Occasionally, an insect known as the Cuban May beetle may cause some defoliation. Season: Jan.-Sept. (some all year).

\section{Mango}

Mango trees are native to southeast Asia and India. Hardly a new comer to Florida, mango trees have been planted and enjoyed for over 100 years in Florida. Mango trees are medium to large trees (up to $100 \mathrm{ft}$ ) and there is a wide variety of cultivars available with varying shapes, colors and maturities. Most mangoes are ripe when the fruit softens slightly and takes on a yellow to orange or red color and carries a subtle sweet fragrance. Mangoes are a good source of vitamins A and C. They can be eaten fresh or pureed. Perhaps more than any other tropical fruit, mangoes are readily available at many local nurseries and garden centers. Trees are tough and relatively easy to grow. Most varieties of grafted trees will bear in as little as 3-5 years after transplanting. Season: May-Oct.

\section{Papaya}

Indigenous to southern Mexico, Central and South America, papaya plants are relatively short lived (1-3 years) and are easily propagated from seed. Papayas are relatively easy to grow so long as they are sited in full sun and have excellent drainage. Common throughout the tropics, papayas are small to large fruits born on the stem of upright semi-herbaceous trunks. Fruit are sweet, have orange to reddish-salmon colored flesh and contain numerous small black seeds in the interior cavity. Papaya fruit is typically peeled, sliced and consumed fresh. Papaya ringspot virus can be a problem causing stunting and fruit loss; at present there is no control for this disease. Papaya fruit fly is another problem but can be overcome by placing a 3-5 pound paper bag over developing fruit. Amend the soil with plenty of organic matter and fertilize often. Season: year round.

\section{Passion Fruit}

Native to South America, passion fruit is a vigorous vine that produces purple, yellow, or reddish colored fruit containing seeds surrounded by an orange, sweet, watery pulp. The juice is very aromatic and is commonly used to make juice or punch. Plant vines next to a fence or along a trellis in a well drained soil area with full sun. Vines begin to bear within 3-6 months of planting. Season June-Dec.

\section{Sugar Apple (annon, sweetsop)}

Native to tropical America, the sugar apple, is also called sweetsop or anon, has been widely planted in home gardens of south Florida because of its high quality fruit. It is a small, open, deciduous tree with a rounded canopy, rarely exceeding 20 feet in height 
and width. Because of their small stature, sugar apple trees are suited to small yards. The fruit is heart-shaped, round, ovate or conical, from 2 to 4 inches in diameter. The pulp is white or creamy white, with a custard-like consistency and a sweet, pleasant flavor. When ripe, sugar apples become light green or yellow-green in color. The sugar apple is consumed principally as a dessert fruit. A relative of the sugar apple called atemoya has similar characteristics to sugar apple. The pulp of sugar apple has an excellent flavor and is usually eaten fresh but it may also be used to make tasty ice cream or milkshakes. Season: July-Sept., Nov. -Jan.

\section{Tamarind}

Indigenous to tropical Africa, tamarind is a sturdy, slow growing but large (up to $80 \mathrm{ft}$ ) leguminous tree with rough bark, twisting spreading branches and finely pinnate, evergreen foliage. Flowers are pale yellow with red veins and born in small racemes in early summer. The fruit are brown pods measuring 3-8 inches in length containing large seeds embedded in a sticky brown pulp, which is edible. The pulp may have a sweet to sour molasses-like flavor, can be extracted and used to flavor cooking sauces. It is a primary ingredient in certain brands of steak sauce. Because of the many fissures found on its rough textured bark, tamarind trees provide an excellent substrate for growing orchids. Season: April-June.

\section{Invasive fruit crops}

\section{Guava}

Guava has been assessed by the IFAS Invasive Plants Working Group as invasive and not recommended by IFAS for planting in south Florida; guava may be planted in central Florida but should be managed to prevent escape. ${ }^{1}$

Native to southern Mexico and Central America, guava trees are small, seldom exceeding 20 feet and quite easy to grow. Fruit are produced throughout the year, but the bulk of production in Florida occurs during the summer months. Up to a $25 \mathrm{lbs}$ of fruit per tree can be expected three years after planting, increasing to 100-250 lbs per year when trees attain maturity. Fruit are ripe when flesh softens slightly and turns a light yellow. Depending upon the variety, interior flesh can be white, yellow, pink or red. Cover fruit with a paper bag while small and green to prevent fruit fly damage. Maturing guava must be harvested quickly as birds and insects will readily attack ripe fruit. Guava is tolerant to pruning, which can hasten flower and fruit development. Popular with Hispanic and Asian Americans, guava may be consumed fresh but more often is made into purees, juices and jellies. The fruit has an exotic flavor and aroma. It is an outstanding source of vitamin $\mathrm{C}$, with some varieties having as much as five times the vitamin $\mathrm{C}$ content of fresh orange juice. Season: Aug.-Oct., Feb.-March.

1, For more information see: Fox, A.M., D.R. Gordon, J.A. Dusky, L. Tyson, and R.K. Stocker (2005) IFAS Assessment of the Status of Non-Native Plants in Floridas Natural Areas. Ci ted from the Internet (6 Jan., 2006) http://plants.ifas.ufl.edu/assessment.html

\section{Sapodilla (nispero)}

Sapodilla has been assessed by the IFAS Invasive Plants Working Group as invasive in south and central Florida and is not recommended by IFAS for planting. ${ }^{1}$

Sapodilla also called chicozapote, is a medium to large tree with small, dark green, glossy leaves. The fruit is round to oval in shape with a brown peel; inside is a light to dark brown, sweet flesh. There are a number of good cultivars available from local nurseries. Trees are well adapted to south Florida and they are very ornamental. Plant trees in well drained areas away from other trees and structures. Trees usually begin bearing after 2-4 years from planting. Season: Feb.-June.

1, For more information see: Fox, A.M., D.R. Gordon, J.A. Dusky, L. Tyson, and R.K. Stocker (2005) IFAS Assessment of the Status of Non-Native Plants in Floridas Natural Areas. Ci ted from the Internet (6 Jan., 2006) http://plants.ifas.ufl.edu/assessment.html 


\section{Summary of Cultural Information}

There are numerous tropical and subtropical fruit crops adapted to south Florida's climate. Many tropical and subtropical fruit trees make beautiful specimen trees in the home landscape and provide shade and tasty fruits (Table 1 and Table 2). Some of these fruits are familiar like avocado and mango; others are less well known like carambola and sugar apple. 
Table 1. Common and scientific name, ultimate tree size, recommended planting distance, cold tolerance, water requirement, and harvest season of selected tropical fruit crops.

\begin{tabular}{|c|c|c|c|c|c|c|c|}
\hline $\begin{array}{l}\text { Common } \\
\text { name - } \\
\text { English/ } \\
\text { Spanish }\end{array}$ & Scientific name & $\begin{array}{l}\text { Ultimate } \\
\text { size }^{1}\end{array}$ & $\begin{array}{l}\text { Rec. } \\
\text { distance }^{2}\end{array}$ & $\begin{array}{l}\text { Cold tol. } \\
\left({ }^{\circ} \mathrm{F}\right)^{3}\end{array}$ & $\begin{array}{l}\text { Water } \\
\text { requirement }{ }^{4}\end{array}$ & $\begin{array}{l}\text { Harvest } \\
\text { season }^{5}\end{array}$ & $\begin{array}{l}\text { Rec. for } \\
\text { planting }\end{array}$ \\
\hline $\begin{array}{l}\text { Atemoya/ } \\
\text { annon }\end{array}$ & $\begin{array}{l}\text { Annona } \\
\text { cherimola X A. } \\
\text { squamosa }\end{array}$ & M, 20-30 & $20+$ & $<=32$ & $\begin{array}{l}\text { Low- } \\
\text { moderate }\end{array}$ & $\begin{array}{l}\text { Aug.-Oct., } \\
\text { Dec.-Jan. }\end{array}$ & Yes \\
\hline $\begin{array}{l}\text { Avocado/ } \\
\text { aguacate }\end{array}$ & $\begin{array}{l}\text { Persea } \\
\text { americana }\end{array}$ & $L, 40-50$ & $23-30+$ & $26-30$ & $\begin{array}{l}\text { Low- } \\
\text { moderate }\end{array}$ & $\begin{array}{l}\text { Late } \\
\text { June-March }\end{array}$ & Yes \\
\hline $\begin{array}{l}\text { Banana } \\
\text { (eating) }\end{array}$ & Musa spp. & S, 5-20 & $12-15+$ & $<=28$ & High & All year & Yes \\
\hline $\begin{array}{l}\text { Star apple/ } \\
\text { caimito }\end{array}$ & $\begin{array}{l}\text { Chrysophyllum } \\
\text { cainito }\end{array}$ & L, 30-40 & $23-30+$ & $29-31$ & $\begin{array}{l}\text { Low- } \\
\text { moderate }\end{array}$ & Feb.-June & Yes \\
\hline Carambola & $\begin{array}{l}\text { Averrhoa } \\
\text { carambola }\end{array}$ & M, 30-35 & $15-20+$ & $27-32$ & High & $\begin{array}{l}\text { July-Oct.+ } \\
\text { Nov.-Feb. }\end{array}$ & Yes \\
\hline $\begin{array}{l}\text { Canistel/ } \\
\text { egg fruit }\end{array}$ & $\begin{array}{l}\text { Pouteria } \\
\text { campechiana }\end{array}$ & L, 30-40 & $23-30+$ & $26-32$ & $\begin{array}{l}\text { Low- } \\
\text { moderate }\end{array}$ & $\begin{array}{l}\text { Nov.-March } \\
\text { (irregular) }\end{array}$ & Yes \\
\hline Jaboticaba & $\begin{array}{l}\text { Myrciaria } \\
\text { cauliflora } \\
\end{array}$ & $\mathrm{M}, \sim 30$ & $15-20$ & $<=29$ & Low & $\begin{array}{l}\text { Variable, all } \\
\text { year }\end{array}$ & Yes \\
\hline $\begin{array}{l}\text { Jackfruit/ } \\
\text { jakfruit }\end{array}$ & $\begin{array}{l}\text { Artocarpus } \\
\text { heterophyllus }\end{array}$ & L, 40-50 & $23-30+$ & $<=32$ & Moderate & $\begin{array}{l}\text { Spring-fall } \\
\text { (some all } \\
\text { year) }\end{array}$ & Yes \\
\hline $\begin{array}{l}\text { Longan/ } \\
\text { momocillo } \\
\text { chino }\end{array}$ & $\begin{array}{l}\text { Nephelium } \\
\text { longana }\end{array}$ & L, $40-50$ & $23-30+$ & $28-30$ & $\begin{array}{l}\text { Moderate- } \\
\text { high }\end{array}$ & $\begin{array}{l}\text { July, early } \\
\text { Aug. }\end{array}$ & Yes \\
\hline $\begin{array}{l}\text { Lychee/ } \\
\text { momocillo } \\
\text { chino }\end{array}$ & Litchi chinensis & $\mathrm{L}, \sim 40$ & $23-30+$ & $28-32$ & Moderate & $\begin{array}{l}\text { June, early } \\
\text { July }\end{array}$ & Yes \\
\hline $\begin{array}{l}\text { Mamey } \\
\text { sapote/ } \\
\text { mamey } \\
\text { colorado }\end{array}$ & Pouteria sapota & $L, 40-50$ & $23-30+$ & $28-32$ & High & $\begin{array}{l}\text { Jan.-Sept } \\
\text { (some all } \\
\text { year) }\end{array}$ & Yes \\
\hline Mango & Mangifera indica & L, 40-60 & $23-30+$ & $28-30$ & $\begin{array}{l}\text { Low- } \\
\text { moderate }\end{array}$ & May-Oct. & Yes \\
\hline Papaya & Carica papaya & $S, \sim 20$ & $6-15+$ & $<=30$ & High & All year & Yes \\
\hline $\begin{array}{l}\text { Passion fruit/ } \\
\text { maracuyá }\end{array}$ & $\begin{array}{l}\text { Passiflora edulis } \\
\text { \& f. flavicarpa }\end{array}$ & vine & $12-20+$ & $<=32$ & High & June-Dec. & Yes \\
\hline $\begin{array}{l}\text { Sugar } \\
\text { apple/anon }\end{array}$ & $\begin{array}{l}\text { Annona } \\
\text { squamosa }\end{array}$ & S, 20 & $15-20+$ & $28-30$ & $\begin{array}{l}\text { Low- } \\
\text { moderate }\end{array}$ & $\begin{array}{l}\text { July-Sept.+ } \\
\text { Nov.-Jan. }\end{array}$ & Yes \\
\hline $\begin{array}{l}\text { Tamarind/ } \\
\text { tamarindo }\end{array}$ & $\begin{array}{l}\text { Tamarindus } \\
\text { indica }\end{array}$ & L, 60-80 & $25-30+$ & $28-32$ & Low & April-June & Yes \\
\hline \multicolumn{8}{|c|}{$\begin{array}{l}\text { 1, Ultimate size (ft), height of mature tree if not pruned, } S=s m a l l, M=\text { medium, } L=l a r g e ; 2, \text { Planting distance, planting } \\
\text { distance to nearest structure or tree. This will vary depending upon purpose of tree, i.e., fruit production or primarily shade; } \\
3 \text {, Temperatures at or below which cold damage may occur; } 4 \text {, Water requirement during the warm period of the year. The } \\
\text { water needs of most trees decreases during the winter months. Exceptions are banana, plantain, and papaya, which } \\
\text { require sufficient water throughout the year; } 5 \text {, Harvest season may vary with climate and/or variety; } 6 \text {, Rec., } \\
\text { recommendation. Note: Guava has been assessed as invasive and not recommended by IFAS for planting in south } \\
\text { Florida; guava may be planted in central Florida but should be managed to prevent escape. Sapodilla has been assessed } \\
\text { as invasive in south and central Florida and is not recommended by IFAS for planting. }\end{array}$} \\
\hline
\end{tabular}


Table 2. Recommended fertilizer practices for selected young $(Y)$ and mature $(M)$ tropical fruit crops.

\begin{tabular}{|c|c|}
\hline Fruit crop & Recommended fertilizer practices $^{1,2,3}$ \\
\hline Atemoya & $\begin{array}{l}\text { Y: } 1 / 4 \mathrm{lb} \text {. per tree bimonthly - increase amount with tree size. M: } 1-3 \mathrm{lbs} \text {. per tree, } \\
\text { 3-5 applications per year; maximum per year, } 15-18 \mathrm{lbs} \text {. }\end{array}$ \\
\hline Avocado & $\begin{array}{l}\text { Y: } 1 / 4 \mathrm{lb} \text {. per tree bimonthly - increase amount with tree size. M: } 4-5 \mathrm{lbs} \text {. per tree, } \\
\text { 3-5 applications per year; maximum per year, } 20-25 \mathrm{lbs} \text {. }\end{array}$ \\
\hline Banana & $\begin{array}{l}\text { Y: } 1 / 4-1 \mathrm{lb} \text {. per tree bimonthly - increase amount with tree size. Use a 6-2-12 or } \\
\text { similar fertilizer. M: (after plants are } 10-15 \text { months old) 5-6 lbs. per tree bimonthly; } \\
\text { maximum per year, } 10-12 \mathrm{lbs} \text {. }\end{array}$ \\
\hline Caimito & $\begin{array}{l}\text { Y: } 1 / 4 \mathrm{lb} \text {. per tree bimonthly - increase amount with tree size. M: } 4-5 \mathrm{lbs} \text {. per tree, } \\
\text { 3-5 applications per year; maximum per year, } 20-25 \mathrm{lbs} \text {. }\end{array}$ \\
\hline Carambola & $\begin{array}{l}\text { Y: } 1 / 4-1 \mathrm{lb} \text {. per tree bimonthly - increase amount with tree size. } \mathrm{M}: 4-5 \mathrm{lb} \text {. per } \\
\text { tree, 4-6 applications per year; maximum per year, } 20-25 \mathrm{lbs} \text {. }\end{array}$ \\
\hline Canistel & $\begin{array}{l}\text { Y: } 1 / 4 \mathrm{lb} \text {. per tree bimonthly - increase amount with tree size. M: } 4-5 \mathrm{lbs} \text {. per tree, } \\
\text { 3-5 applications per year; maximum per year, } 15-20 \mathrm{lbs} \text {. }\end{array}$ \\
\hline Jaboticaba & $\begin{array}{l}\text { Y: } 1 / 4 \mathrm{lb} \text {. per tree per month the first year, every } 2 \text { nd month the second year, and } \\
\text { every } 3 \text { rd month the third year. M: } 1-2 \mathrm{lbs} \text {. per tree, } 3-4 \text { applications per year; } \\
\text { maximum per year, 3-8 lbs. }\end{array}$ \\
\hline Jackfruit & $\begin{array}{l}\text { Y: } 1 / 4-1 / 2 \mathrm{lb} \text {. per tree every } 6-8 \text { weeks the first year - increase amount with tree } \\
\text { size. M: } 1-5 \mathrm{lbs} \text {. per tree, } 3-5 \text { applications per year; maximum per year, } 20-25 \\
\text { lbs. }\end{array}$ \\
\hline Longan & $\begin{array}{l}\text { Y: } 1 / 4 \mathrm{lb} \text {. per tree bimonthly - increase amount with tree size. M: 3-5 lbs. per tree, } \\
\text { 3-5 applications per year; maximum per year, } 15 \mathrm{lbs} \text {. }\end{array}$ \\
\hline Lychee & $\begin{array}{l}\text { Y: } 1 / 2-1 \mathrm{lb} \text {. per tree every } 6-8 \text { weeks - increase amount with tree size. M: } 3-5 \mathrm{lbs} \text {. } \\
\text { per tree, 3-5 applications per year; maximum per year, } 15 \mathrm{lbs} \text {. }\end{array}$ \\
\hline $\begin{array}{l}\text { Mamey } \\
\text { sapote }\end{array}$ & $\begin{array}{l}\text { Y: } 1 / 4 \mathrm{lb} \text {. per tree bimonthly - increase amount with tree size. M: } 3-5 \mathrm{lbs} \text {. per tree, } \\
\text { 3-5 applications per year; maximum per year, } 20-25 \mathrm{lbs} \text {. }\end{array}$ \\
\hline Mango & $\begin{array}{l}\text { Y: } 1 / 4-1 / 2 \mathrm{lb} \text {. per tree every } 6-8 \text { weeks the first year - increase with tree size. M: } \\
\text { 3-5 lbs. per tree, } 3-5 \text { applications per year; maximum per year, } 15-20 \mathrm{lbs} \text {. }\end{array}$ \\
\hline Papaya & $\begin{array}{l}\text { Y: } 1 / 2 \mathrm{lb} \text {. per tree every } 2-3 \text { weeks. Increase the amount to } 11 / 2 \mathrm{lb} \text {. per tree until } \\
\text { plants are } 7-8 \text { months old. } \mathrm{M}: 11 / 2 \mathrm{lb} \text {. per tree per month; maximum per year, } \\
18-24 \mathrm{lbs} \text {. }\end{array}$ \\
\hline Passion fruit & $\begin{array}{l}\text { Y: 4-6 oz. per vine, 4-6 applications per year. M: 1-2 lbs. per vine, 3-5 } \\
\text { applications per year; maximum per year, } 6-12 \mathrm{lbs} \text {. }\end{array}$ \\
\hline Sugar apple & $\begin{array}{l}\mathrm{Y}: 1 / 4 \mathrm{lb} . \text { per mo. per tree - increase with tree size. M: 1-4 lb. per tree, 3-5 } \\
\text { applications per year; maximum per year, } 15-20 \mathrm{lbs} \text {. }\end{array}$ \\
\hline Tamarind & $\begin{array}{l}\text { Y: } 1 / 4 \mathrm{lb} \text {. per tree every } 2-3 \text { months - increase with tree size. M: } 3-5 \mathrm{lb} \text {. per tree, } \\
\text { 2-3 applications per year; maximum per year, } 15-20 \mathrm{lbs} \text {. }\end{array}$ \\
\hline \multicolumn{2}{|c|}{$\begin{array}{l}\text { 1, Common fertilizer ratios may be used such as } 6-6-6,8-3-9,8-2-8,10-10-10 \text {, or similar materials. } \\
\text { 2, Y, young trees; M, mature trees. } \\
\text { 3, Apply minor elements (manganese, zinc) in a foliar spray 3-4 times during the growing season } \\
\text { (April-Sept.). Apply iron in a soil drench (water plus iron) 3-4 times during the growing season } \\
\text { (June-Sept.best). }\end{array}$} \\
\hline
\end{tabular}

